new knowledge resulting from present-day research. The report sites its investigations in the cryogenies field which have led to the sponsorship of the eryogenic engineering project and its efforts to encourage in tho United Kingdom the establishment of adequate industrial facilities in this field. Its investigations in relation to the mechanical properties of solids are also noted. A conference sponsored at the University of Cambridge in July 1961 to formulate proposals for research and development in this rolatively new field aroused considerable interest. The tempo of work generally was increased and programmes have been expanded to take note of the recommendations of this conference, and steps are being taken to co-ordinate the work being carried out in the public research establishments.

It may be for consideration how far the National Research Development Corporation should function in this way and whether it is not here entering on activities which the Council for Seientific and Industrial Research should be fostering. If the Corporation through its experience has a vital contribution to make, activities of this kind provide one strong reason for placing it in closer relation to the Department of Scientific and Industrial Research and within the survey and responsibility of the Minister for Science rather than the Board of Trade. Some clear thinking on these and related issues is imperative when the whole structure of Government organization for civil research and devolopment comes under review.

\section{RADIOBIOLOGY'S EXPANDING FUNDAMENTALS}

Fundamentals of Radiobiology

By Z. M. Bacq and Peter Alexander. Complete revised second edition. (International Series of Monographs on Pure and Applied Biology. Division: Modern Trends in Physiological Sciences, Vol. 5.) Pp. xii +555. (London and New York: Pergamon Press, 1961.) 70s. net.

IN $\mathrm{N}$ the preface of the first edition of this book, the authors remarked on the diversity of disciplines involved in radiobiological work, and radiobiologists do indeed noed to have an acquaintance, at least, with a wide variety of subjects. The difficulties for beginners in this field can easily be imagined, and a brief but adequate survey of the basic facts and present working hypotheses is very necessary for them. The 350 pages of the first edition proved to be a very useful text for this purpose, but the second edition runs to more then 500 larger pages and the tiro's task has thus increased. Much new material has been incorporated and the increase in size is in many ways an indication of the enormous number of radio. biological publications during the six years between the editions. An increase in the amount of data available. however, should not necessarily mean an increase in the 'fundamentals' of a subject. As the authors have resisted the temptation to change their title when they changed publishers, it is hoped that they will resist the temptation of turning their volume into a large text-book. Perhaps this second edition is merely suffering from the adiposity of adolescence, in which case we can look forward to the third and fourth editions regaining the slimness of the youthful Fundamentals.

The book is, however, still unique in its gener'sl usefulness and no other covers the scientific aspects of the subject so well. Although primarily intended for beginners, more experienced workers will, no doubt, refer to it for guidance in those aspects of the subjects outside their own field. These latter users will find a good deal of extra information and some shifts of emphasis in the new edition. The nature of the initial chemical lesion is stressed, the chapter on radiation effects on macromolecules has almost doubled in size and the section on "alteration of permeability in cells" is replaced by one on "the enzymerelease hypothesis". The chapters on the processes of restoration and the physiopathology of radiation sicknes: are greatly expanded and there are new chapters on delayod effects and the intoraction between cells and tissues following irradiation. As one would expect from these authors the chapter on chemical protection is particularly useful. Genetic effects of radiation are only very briefly described.

This is not an impersonal book, and it is pleasant to note. how the authors are ready to becomo expansive whon they reach their own interests and how, after marshalling is number of theories, they are ready to offer summaries and conclusions. There is sometimes a lack of clarity in the writing and in some parts peculiar phraseology is used; for example, "profound trouble in cholesterol synthesis" (p. 399). Misprints, even when acknowledging illustrations (for example, Figs. $20-2$ and $20-3$ ), and error's such as "polynucleated" instead of "polymorpho. nuclested" and "pienotic" instead of "pyknotic" are not uncommon. Numerous reforences follow each chapter, but occasionally they are not mentioned in the text, and in one instance experiments are attributed to an author which he did not do and a conclusion which he did not draw.

E. V. Hulsh

\section{CLASSICAL PROBLEMS IN PHYSICS}

\section{Cavendish Problems in Classical Physics}

Edited by Prof. A. B. Pippard. Compiled by the Staff of the Cavendish Laboratory, Cambridge. Pp. $x+51$. (Cambridge : At the University Press. 1962.) 5s. 6d. net: 1 dollar.

$\mathrm{N}$ the preface to this excollent collection of problems. 1 Prof. Pippard mentions the situation that faces university teachers of physies. It is necessary to move with the times, and to spare no efforts to make physics, and a career in physics, attractive to students. "No amount of exciting new presentations of the basic ideas is going to make it easy for the student to acquire professional competence. If he cannot make a good showing at these classical problems all his expertise in the realm of ideas is so much vanity; for they are examples of what will continually confront him in the practice of his art." What he is really saying was said long ago, that there is no royal road; and as improved teaching takes the drudgery out of learning. the discipline must still remain. The observations in the preface are wise, and relevant to physies teaching at all levels nowadays; though ono feels that Prof. Pippard is inconsistent in saying that the conversion of electrica! units is responsible for more error than anything else in physics, and also chiding as folly the views of those who settle for avoiding conversions.

The problems are varied and challenging. Some are straightforward calculations, a few are standard theorems. many involve the two- or three-stage application of elementary principles and would be within the scope of a scholarship candidate; others, not too difficult in principle, require a mature mathematical approach. They find the chinks in the armour, too ; of two equally innocent-looking examples, I did one in my head and spent a fruitless hour on the other. In general, the forty or so questions on thermodynamies seem to be more exacting than the rest-perhaps because they offer the inquisitor more scope, or it may be that one meets this type of question less regularly and is less able to judge.

A selection of classical problems naturally includes examples gross as Earth; and besides satellites and rockets there is one about the building of the Great Pyramid. 